\title{
Financial Condition as an Object of Accounting and Analytical Support and Internal Control
}

\author{
Anton Chepulyanis*, Natalia Mokina, and Irina Vlasova \\ Ural State University of Economics, 620144 Yekaterinburg, Russia
}

\begin{abstract}
The article presents theoretical and organizational and methodological aspects of accounting and analytical support and internal control of the financial condition of the organization. The authors highlight the main directions of interpretation of the definition of "financial condition", and provide the author's definition of this category. The paper describes the process of information support for managing the financial condition of an organization, and reveals its main blocks. The article also provides a methodology for accounting and analytical support of the financial condition forecasting process.
\end{abstract}

\section{Introduction}

Estimation of the financial condition of each economic entity has a significant role in forming a professional judgment about the viability of a business, its ability to attract additional resources, the team's ability to generate its own sources of business financing and ensure the efficiency and effectiveness of all business processes. To form a holistic understanding of the financial condition, it is necessary to provide reliable and complete information about the position of property and funding sources, as well as correlate them with performance indicators of economic activity.

For these purposes, an integrated system of accounting and analytical support and internal control is being built, designed to form an array of information and integrated indicators of a financial and non-financial nature, reflecting the true state of affairs in the company to ensure operational (current) and strategic management of the financial condition of the organization.

\section{The essence of the financial condition and its characteristics}

Currently, the concept and essence of the category "financial condition" is debatable and has a multi-aspect nature. Based on the conducted literary review, the following directions in the interpretation of the financial condition were highlighted, presented in Table 1.

\footnotetext{
*Corresponding author: anthonas@yandex.ru
} 
Table 1. Directions in the interpretation of the category "financial condition" [1,2].

\begin{tabular}{|c|c|c|}
\hline Direction & Supporters & Category essence \\
\hline $\begin{array}{l}\text { Financial } \\
\text { condition as a } \\
\text { system of } \\
\text { economic and } \\
\text { financial relations }\end{array}$ & $\begin{array}{l}\text { T.A. Gorodnyaya, } \\
\text { R.L. Lupak, O.V. } \\
\text { Ivaniv, A.M. } \\
\text { Podderegin }\end{array}$ & $\begin{array}{l}\text { Financial condition is an economic relationship } \\
\text { associated with the placement and use of assets } \\
\text { (property) and their formation sources }\end{array}$ \\
\hline $\begin{array}{l}\text { Financial } \\
\text { condition as a } \\
\text { system (set) of } \\
\text { indicators, } \\
\text { characteristics }\end{array}$ & $\begin{array}{l}\text { S.I. Krylov, A. } \\
\text { Abedi, V.V. } \\
\text { Kovalev, O.N. } \\
\text { Volkova }\end{array}$ & $\begin{array}{l}\text { Financial condition is an integrated characteristic of } \\
\text { an organization's activities, including indicators } \\
\text { (indicators): } \\
\text { - property status; } \\
\text { - the state of the organization's capital; } \\
\text { - indicators of liquidity and solvency; } \\
\text { - indicators of profitability and business activity } \\
\text { (economic efficiency of using property and capital) } \\
\text { - indicators of financial stability; } \\
\text { - indicators of viability (assessment of the likelihood } \\
\text { of bankruptcy and insolvency). }\end{array}$ \\
\hline $\begin{array}{l}\text { Financial } \\
\text { condition as a } \\
\text { level (degree) of } \\
\text { resource } \\
\text { provision }\end{array}$ & $\begin{array}{l}\text { K.S. Saliga, E.Yu. } \\
\text { Tkachenko, V. } \\
\text { Bandurk, N. } \\
\text { Korobov, P. Orlov, } \\
\text { K. Petrova, A.N. } \\
\text { Tishchenko, N.A. } \\
\text { Kizim, Ya. V. } \\
\text { Dogadaylo }\end{array}$ & $\begin{array}{l}\text { Financial condition is a complex qualitative } \\
\text { indicator that reflects the provision of an enterprise } \\
\text { and all its business processes with the necessary } \\
\text { material, intangible and financial resources, as well } \\
\text { as characterizing the efficiency and rationality of } \\
\text { their use. }\end{array}$ \\
\hline $\begin{array}{l}\text { Financial } \\
\text { condition as a } \\
\text { component } \\
\text { (element) of } \\
\text { economic } \\
\text { potential }\end{array}$ & $\begin{array}{l}\text { T.G. Sheshukova, } \\
\text { E.V. Kolesen }\end{array}$ & $\begin{array}{l}\text { Financial condition is a strategic indicator of the } \\
\text { development and financial potential of an } \\
\text { organization, reflecting the cost and value of a } \\
\text { business, determining the competitiveness and } \\
\text { positioning of an economic entity in terms of the } \\
\text { prospective financial stability of a business in } \\
\text { comparison with other market participants. }\end{array}$ \\
\hline
\end{tabular}

From Table 1, we can conclude that financial condition is an integral indicator of sustainable development and functioning of an economic entity. This indicator is reflected in the system of financial and non-financial indicators, characterizes the effectiveness of economic relations with other business entities, reflects the current and future provision of all business processes with the necessary resources (material, intangible, financial).

\section{System of accounting and analytical support of the financial condition of the organization}

The information process for managing the financial position of an organization can be represented as a value chain (Fig. 1), where accounting, analytical and controlling procedures will be included in the complex of basic processes. Overhead processes will include procedures that ensure the continuity and control of the main processes. 


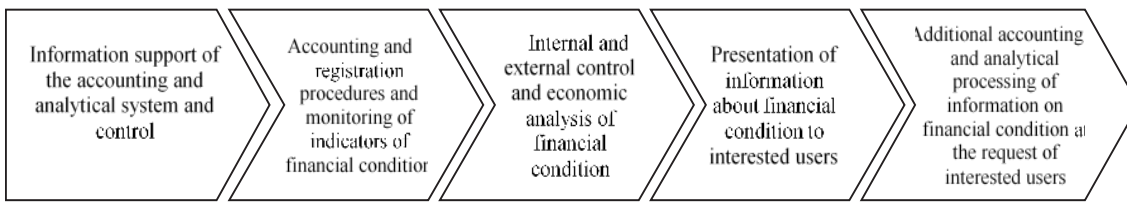

\begin{tabular}{|c|}
\hline Staffing and HR management \\
\hline \hline Quality Management System \\
\hline \hline IT-support and software \\
\hline Risk management \\
\hline
\end{tabular}

Fig. 1. Management information process financial condition of the organization

The block "Information support" includes the means and sources of information about the state of property, liabilities, own sources of the organization's asset formation; it also includes external sources of information about the state of the external and working environment of the organization, which can have a significant impact on the indicators of the financial condition of the organization in the current period and in the future. Thus, in this block, an array of data on the main indicators of the financial condition of the external and internal contours of the organization is formed.

In the block "Accounting", the monitoring, registration, accumulation and systematization of the data array obtained at the first stage of the information process is carried out. The information is grouped by means of accounting methods: documentation, double entry, accounting modeling (accounting engineering). The information is reflected in special accounting registers, then aggregated in the system of internal and external reports, which will be further interpreted. [3]

The third block "Analysis and Control" is a set of procedures for checking the completeness and reliability of the facts of the organization's economic life reflected in the accounting subsystem that determine the state of property, liabilities and own sources of funding. At the same stage, procedures are performed for the analytical interpretation and assessment of the main indicators of the financial condition of the organization, conclusions are drawn about the compliance or deviation of the actual values of indicators from the standards and quality criteria. Based on the control and analytical procedures, a conclusion is made on further regulatory actions in relation to the financial condition: in the event of a significant deviation in relative indicators, a set of measures is being developed to normalize the main components of the financial condition.

In the block "Presentation to interested users", information on the financial condition of the organization is disclosed for different groups of users in accordance with their requirements and requests. At this stage, users' satisfaction with the volume and quality of the information provided is also assessed. Internal users usually require more detailed information with disclosure of factors and drivers that influenced structural and dynamic shifts in the composition of assets and liabilities of the balance sheet and relative indicators of financial condition. In turn, external users need more aggregated information to make informed economic decisions on further or prospective interaction with the organization.

If users are not satisfied with the volume and completeness of the information provided on the financial condition of the organization, additional accounting and analytical processing can be performed to satisfy the request (Block "Additional processing"). This approach to providing information to users has a positive impact on the investment attractiveness of a business. 


\section{Methodology for accounting and analytical support for predicting the financial condition of an organization}

To manage the financial condition of an organization, it is necessary to be able not only to assess and take into account its current state, but also to be able to predict it for the near future (as a rule, it is a 3-5 year). When forecasting, it is necessary to be guided by the principles presented in Table 2 of this work. At the same time, the role of accounting and analytical support in forecasting the financial condition consists in information support of forecasts with retrospective and planned economic data of a financial and non-financial nature, on the basis of which the forecast model is built. Also, accounting and analytical support is involved in monitoring and assessing the achievement of promising and strategic parameters of economic activity.

Table 2. Principles of forecasting the financial condition of an organization.

\begin{tabular}{|c|l|}
\hline $\begin{array}{c}\text { Forecasting } \\
\text { principle }\end{array}$ & \multicolumn{1}{c|}{ Characteristics of the principle } \\
\hline Variability & $\begin{array}{l}\text { When forecasting any process, several scenarios for the development of the } \\
\text { financial situation arise, therefore, when predicting the indicators of the financial } \\
\text { condition, it is necessary to consider several options for forecast reporting based } \\
\text { on the current state and trends in the internal and external environment of the } \\
\text { company. }\end{array}$ \\
\hline $\begin{array}{l}\text { Consistency } \\
\text { (complexity) }\end{array}$ & $\begin{array}{l}\text { This principle implies that when predicting financial indicators, it is necessary } \\
\text { to approach in a comprehensive manner and interconnect both the main and } \\
\text { indirect factors affecting the projected financial condition of the organization. } \\
\text { This will provide more accurate and objective parameters of the future financial } \\
\text { position. }\end{array}$ \\
\hline $\begin{array}{l}\text { Going- } \\
\text { concern }\end{array}$ & $\begin{array}{l}\text { When forecasting, it is necessary to take into account the fundamental principle } \\
\text { of any business - going-concern. Therefore, when predicting the financial } \\
\text { condition, it is necessary to focus on preventing the situation of bankruptcy } \\
\text { (insolvency) of an economic entity. }\end{array}$ \\
\hline Adaptability & $\begin{array}{l}\text { The environment tends to change dramatically due to various external factors, } \\
\text { which are practically not affected by the organization. Consequently, the } \\
\text { predictive model of the financial condition must be adaptable to abrupt changes } \\
\text { in the external environment, it must contain reserves that would significantly } \\
\text { compensate and neutralize the negative corrective effects of the environment. }\end{array}$ \\
\hline
\end{tabular}

The methodology for forecasting the financial condition of an organization includes 3 stages:

Stage 1: Assessment of the current financial condition of the organization

For the purposes of further forecasting, a comprehensive financial analysis of the financial condition is carried out. On the basis of the analysis, "painful" points are identified that reduce its qualitative characteristics, form risk factors for the loss of financial stability, reduce business activity and the efficiency of economic activity. When predicting the future financial condition, special attention should be paid to these reference points, and during implementation - to control and regulate compliance with the specified parameters. [4]

Stage 2: Modeling and parameterization of the financial condition

Using the methods of accounting engineering, economic and mathematical modeling, regression analysis, strategic parameters of the financial condition are set, strategic derivative reports are developed for all elements of the financial condition system. Strategic parameters are of a probabilistic nature, represent a set of qualitative and quantitative indicators 
reflecting the level of implementation of the company's development goals and preservation of financial potential. [5]

Stage 3: Strategic accounting and strategic analysis of the parameters of the financial condition of the organization

At this stage, the achievement or deviation from the specified strategic parameters of the financial condition is monitored, information of a financial and non-financial nature about the internal and external environment is recorded and systematized based on the system of derived reports, which indirectly or directly affects the change in the financial position of the organization.

At the same stage, a complex of procedures for the strategic analysis of factors (drivers) and indicators of financial condition is carried out, which makes it possible to quickly identify, respond and neutralize their negative change and impact on the financial position of the organization. [11]

Stage 4: Adjustment and subsequent analysis of the forecast model of the financial condition of the organization.

In the event of a significant change in the parameters of management and the external environment, the indicators and values of the forecast model become irrelevant and require their reduction to the conditions of the current economic situation. Gap analysis allows you to assess the level, factors and reasons for deviations from the specified parameters, in order to take them into account in the subsequent forecasting of the financial condition. [6]

\section{Internal control of the financial condition of the organization}

Since the information base for assessing the financial condition of an organization is Financial Statements, as well as accounting information on the basis of which these statements were generated, the quality of assessing the financial condition of the organization depends on their reliability.

Based on this, it becomes necessary to carry out control procedures both at the stage of accounting, reporting, and at the stage of directly assessing the financial condition of the organization.

A feature of the internal control is its deep integration with other processes of the enterprise's activity and management. Control procedures are present in the process of current accounting as control over the correctness of filling in primary documentation, creating accounting records, evaluating professional accounting judgments and generating accounting data. At the stage of economic analysis, the compliance of actual indicators with planned and (or) normative ones is monitored, a critical assessment of the actual results of activities is carried out, weaknesses are identified, and in some cases "markers" of non-standard values, violations of management tasks and set goals or even the current legislation.

From the point of view of the organizational and functional structure of internal control at the enterprise, two forms can be distinguished [7]:

- internal audit;

- structural and functional form of internal control.

Organization of internal control in the form of internal audit is inherent in large and some medium-sized companies with a complex organizational structure, financial, material and management resources, aimed, among other things, at obtaining an objective assessment of the company's financial condition. [8]

In accordance with International Standards on Auditing (ISA) 610 "Using the Work of Internal Auditors" the company's internal audit function provides assurance and consulting activities aimed at assessing and improving the effectiveness of the organization's corporate governance, risk management, and internal control processes. 
With the structural and functional form of internal control, a separate control unit is absent, and control functions are provided to one extent or another in the job descriptions of employees.

The concept of internal control is currently being developed at the legislative level. [9]

In accordance with ISA 315 "Identifying and Assessing the Risks of Material Misstatement through Understanding the Entity and Its Environment" internal control is the processes that are designed, implemented, and maintained by those charged with governance, management and other people within the entity to provide reasonable assurance about to achieve the organization's objectives for reliable financial reporting, performance and efficiency, and compliance with applicable laws and regulations.

The position of the Ministry of Finance of Russia regarding the internal control system is disclosed in Information No. PZ-11/2013 [12], according to which internal control is a process aimed at obtaining sufficient confidence that an economic entity provides:

- efficiency and effectiveness of its activities, including the achievement of financial and operational indicators, safety of assets;

- reliability and timeliness of accounting (financial) and other reports;

- compliance with applicable law, including when committing the facts of economic life and accounting.

One of the objects of internal control is the assessment of the financial condition of the organization.

In this regard, internal control contributes to the achievement of the planned or expected level of financial condition. It should ensure the prevention or detection of deviations from normal or planned indicators of financial condition. [10]

It is necessary to highlight such an element of internal control as the process of identifying and analyzing the risks of failure by an economic entity to achieve the planned performance results. In terms of assessing the risks of distortion of information about the financial condition of the organization, one can pay attention to the following groups of errors and distortions (Table 3).

Table 3. Risks of distortion of information about financial condition

\begin{tabular}{|c|l|l|l|}
\hline $\begin{array}{c}\text { Accounting } \\
\text { assumptions }\end{array}$ & \multicolumn{1}{c|}{$\begin{array}{c}\text { Characteristics of the } \\
\text { assumption }\end{array}$} & \multicolumn{1}{c|}{$\begin{array}{c}\text { Error or distortion } \\
\text { characteristic }\end{array}$} & $\begin{array}{l}\text { Impact on the assessment } \\
\text { of the financial condition } \\
\text { of the organization }\end{array}$ \\
\hline Origin & $\begin{array}{l}\text { The facts of economic life, } \\
\text { reflected in accounting and } \\
\text { financial statements, took place } \\
\text { in the reporting period }\end{array}$ & $\begin{array}{l}\text { Untimely reflection of facts } \\
\text { in accounting; } \\
\text { Distortion of comparable } \\
\text { accounting data }\end{array}$ & $\begin{array}{l}\text { Distortion of indicators of } \\
\text { dynamics and rates of } \\
\text { growth of indicators of } \\
\text { financial condition }\end{array}$ \\
\hline Existence & $\begin{array}{l}\text { The facts of economic life, } \\
\text { reflected in accounting and } \\
\text { financial statements, actually } \\
\text { exist }\end{array}$ & $\begin{array}{l}\text { Reflection of non-existent } \\
\text { assets, liabilities, income, } \\
\text { expenses and business } \\
\text { transactions }\end{array}$ & $\begin{array}{l}\text { Overestimation of } \\
\text { indicators of financial } \\
\text { condition }\end{array}$ \\
\hline Completeness & $\begin{array}{l}\text { The facts of economic life that } \\
\text { took place in the reporting } \\
\text { period and to be attributed to } \\
\text { this period are actually reflected } \\
\text { in the accounting and financial } \\
\text { statements }\end{array}$ & $\begin{array}{l}\text { The facts of activity are not } \\
\text { fully reflected in } \\
\text { accounting, there are } \\
\text { significant omissions of } \\
\text { information }\end{array}$ & $\begin{array}{l}\text { Understatement of } \\
\text { financial indicators }\end{array}$ \\
\hline $\begin{array}{l}\text { Rights and } \\
\text { obligations }\end{array}$ & $\begin{array}{l}\text { Property, property rights and } \\
\text { obligations of an economic } \\
\text { entity reflected in accounting } \\
\text { and financial statements refer to } \\
\text { the activities of an economic } \\
\text { entity }\end{array}$ & $\begin{array}{l}\text { There are no rights to } \\
\text { property reflected in } \\
\text { accounting and reporting, } \\
\text { due to the premature } \\
\text { acceptance for accounting } \\
\text { or non-write-off of retired } \\
\text { assets; } \\
\text { Obligations misidentified }\end{array}$ & $\begin{array}{l}\text { Overestimation or } \\
\text { underestimation of } \\
\text { indicators of financial } \\
\text { condition, depending on }\end{array}$ \\
thature of transactions
\end{tabular}


Table 3. Continued

\begin{tabular}{|c|l|l|l|}
\hline Evaluation & $\begin{array}{l}\text { Assets, liabilities, income and } \\
\text { expenses are reflected in the } \\
\text { correct value }\end{array}$ & $\begin{array}{l}\text { Incorrect valuation of } \\
\text { assets, liabilities, income } \\
\text { and expenses }\end{array}$ & $\begin{array}{l}\text { Overestimation or } \\
\text { understatement of } \\
\text { indicators of financial } \\
\text { condition, depending on } \\
\text { the type of asset, liability, } \\
\text { income and expense and } \\
\text { overstatement or } \\
\text { understatement of its value }\end{array}$ \\
\hline Assignment & $\begin{array}{l}\text { Assets, liabilities, income and } \\
\text { expenses are reflected in the } \\
\text { corresponding accounting } \\
\text { accounts and in the } \\
\text { corresponding accounting } \\
\text { registers }\end{array}$ & $\begin{array}{l}\text { Incorrect classification of } \\
\text { assets, liabilities, income } \\
\text { and expenses }\end{array}$ & $\begin{array}{l}\text { Overestimation of certain } \\
\text { indicators and } \\
\text { underestimation of } \\
\text { correlated indicators of } \\
\text { financial condition }\end{array}$ \\
disclosure & $\begin{array}{l}\text { Accounting data are correctly } \\
\text { presented and disclosed in the } \\
\text { accounting (financial) } \\
\text { statements }\end{array}$ & $\begin{array}{l}\text { Distortion of the cost } \\
\text { indicators of the } \\
\text { accounting (financial) } \\
\text { statements, incorrect } \\
\text { classification of indicators, } \\
\text { inadequate description or } \\
\text { explanation of the facts of } \\
\text { activity (including non- } \\
\text { financial information) }\end{array}$ & $\begin{array}{l}\text { Distortion of financial } \\
\text { indicators } \\
\text { Misinterpretation of the } \\
\text { results of the assessment of } \\
\text { financial condition }\end{array}$ \\
\hline
\end{tabular}

It should be noted that all of the above risks of misstatement in the aggregate are comprehensive in terms of their impact on the assessment of the financial condition of the organization, i.e. they affect a set of indicators, and not a single financial ratio.

The materiality of the financial impact of the risks of misstatement will be determined by the magnitude of the particular misstatement or error and its significance to the scale of the business of a particular entity.

Regardless of the materiality of the distortion of indicators for assessing the financial condition of the organization, management decisions made on the basis of inaccurate information may have negative consequences.

In order to prevent the above risks, it is necessary to create a functional control environment, apply certain internal control procedures.

Internal control procedures are actions aimed at minimizing the risks of distortion of the financial condition of an organization. These include:

- control of documentary registration of business transactions;

- confirmation of compliance between accounting objects and documents;

- control over the compliance of accounting objects with established requirements (both legislative and the requirements of business customs adopted by the organization);

- confirmation of the legality of the transactions being carried out;

- data verification;

- control of the actual availability and condition of assets, liabilities;

- monitoring the fulfillment of tasks and plans set by the management, identifying the reasons for non-fulfillment;

- logical and arithmetic verification of accounting information and indicators of Financial Statements;

- control of unauthorized changes in accounting information;

- procedures regulating information security.

Thus, an effective internal control system helps to increase the reliability of assessing the financial condition of an organization. 


\section{Conclusion}

Effective financial management ensures the continuity of economic activities and sustainable development of an economic entity for the long term. At the same time, accounting, analytical and control support serve as a comprehensive tool for maintaining the current and strategic financial condition in the optimal value. The use of predictive models of financial condition allows us to look at the prospects of a business, its ability to provide strategic financial stability and prospective liquidity, which ultimately determine the financial and market potential of the organization, its image in the eyes of stakeholders and potential investors.

\section{References}

1. T.A. Gorodnyaya, R.L. Lupak, O.V. Ivaniv, Biznesinform, 27 (2016)

2. A. V. Kharseeva, Theory and practice of social development, 44 (2008)

3. S.A. Boronenkova., M.V. Melnik, Complex financial analysis in enterprise management: textbook (2016)

4. I. N. Bogataya, Strategic accounting of enterprise property: textbook (2001)

5. V.N. Nezamaikin, Bulletin of the RSUH, 47 (2014)

6. E.M. Evstafieva, Bulletin of the RINH, 177 (2010)

7. V.V. Burtsev, Management in Russia and abroad (2002)

8. M.A. Latypova, N.B. Davletbaeva, Young scientist, 245 (2018)

9. M.S. Manaeva, O.A. Rykalina, Economy and service: from theory to practice, 442 (2018)

10. O.N. Karpacheva, V.S. Matveeva, Innovative development of the economy, 15 (2019)

11. T. G. Sheshukova, E. V. Kolesen, Improving methods for analyzing the economic potential of an economic entity: monograph (2013)

12. Information of the Ministry of Finance of Russia No. PZ-11/2013 